\title{
Ethnic Exclusion, Armed Conflict, and Leader Survival
}

\author{
Hyun Jin Choi
}

\begin{abstract}
Why do some leaders pursue ethnic exclusion even though it increases the risk of ethnic conflict? This article develops and tests a theory that explains how a leader's ethnic policy and the size of the minimum winning coalition interact to influence leader survival. An event history analysis of leadership duration between 1946 and 2012 shows that in non-democratic countries with small winning coalitions: (1) leaders who promote ethnic exclusion are more likely to survive longer in office than those who do not promote such policy; (2) leaders are more likely to be removed from office in a violent manner (e.g. coup d'état) when they fail to employ ethnic exclusion; and (3) political benefits from ethnic exclusion are large enough to offset the risk of being involved in civil war. These findings suggest that ethnic exclusion can be a rational strategy for autocratic leaders even if it might increase the risk of civil war. Political reforms without considering this grim reality are likely to introduce another source of violence and instability in autocratic regimes.
\end{abstract}

Key Words: civil war, ethnic conflict, ethnic exclusion, leader survival, minimum winning coalition

$\mathrm{W}$ hen British rule ended in 1961, Sierra Leone's domestic politics were largely dominated by the Mende people, the largest ethnic group at the time, comprising $36 \%$ of the population. The ruling Sierra Leone People's Party (SLPP) led by Sir Milton Margai was widely perceived as promoting Mende interests, with Mendes filling many of the important positions in civil service (Allen 1968, 309; Horowitz 2000, 474). However, the election of Siaka Stevens, an ethnic Limba, as prime minister effected a drastic change in the composition of the governing coalition. After assuming office in 1968, Stevens began to

\footnotetext{
*Hyun Jin Choi(hyunjin.khu@gmail.com) is an assistant professor in the department of political science at Kyung Hee University in Seoul, Republic of Korea. Prof. Choi's research interests fall within the field of civil war, political violence, sub-Saharan Africa, and political methodology. He received his PhD degree from Michigan State University, MA from the Fletcher School of Law and Diplomacy, and BA from Kyung Hee University. His articles have been published in numerous refereed journals, including International Studies Quarterly, Journal of Conflict Resolution, Global Environmental Change, Comparative Politics, International Interactions, Politics and Religion, and Terrorism and Political Violence.
} 
eliminate his ethnic rivals from political power. First, he purged Mende officers in the army and eliminated the SLPP from electoral competition; he then removed even the Temne-the second largest ethnic group that had allied with him during his rise to power-from key positions in the government, the party, and the army and filled these positions with members of the Limba community. By 1971, Stevens was ruling with the active support of Limbas, who comprised less than $10 \%$ of the population. Although a group of soldiers and civilians, mostly Mende and Temne, plotted a coup d'état in 1974, Stevens survived in power for 18 years, until he peacefully retired from office in November 1985 (Cox 1976, 227-228).

Similar tendencies are observed in Michel Micombero's Burundi (19661976), Idi Amin's Uganda (1972-1979), ${ }^{1}$ Al-Assad family's Syria (1971-Present), and Saddam Hussein's Iraq (1979-2003). In each case, the leader continued to exclude his ethnic rivals from state power until only one, or a small number of, ethnic minorities came to dominate a much larger population. Members of excluded ethnic groups attempted coups or rebellions against the state, but they were easily thwarted by dedicated soldiers who belonged to the same ethnic group as the leader. Despite abounding ethnic grievances and internal military threats to their regimes, these leaders survived relatively long terms in office. One might naturally expect that leaders who promote integration and unity among ethnic groups and thus face lower risks of ethnic rebellion would be more likely to survive longer in office than would those who face violent oppositions within their countries. However, these examples suggest that the opposite could in fact be true. Why is this so? Why do some leaders deliberately foster ethnic hatred and exclusion even to the point of excluding the majority of the population? Further, why do they continue to do so even though such policy might increase the risk of ethnic conflict (Cederman et al. 2010; Wimmer 2013; Wimmer et al. 2009)? In addition, when and under what conditions is ethnic exclusion a rational strategy for leaders, and when does it become self-defeating?

This article attempts to explain the puzzling relationship between ethnic exclusion and leader survival. ${ }^{2}$ In so doing, it considers the role of ethnic ties as a key determinant of membership in the leader's ruling coalition. Rather than conceiving of ethnicity as immutable characteristics (Isaacs 1989; Smith 1986;

\footnotetext{
${ }^{1}$ Idi Amin survived only 7 years in office; he was overthrown not by domestic opposition, but by the invasion of a foreign power.

2 I define ethnic exclusion as the "intentional and targeted" exclusion of elites from particular ethnic categories from state power including key positions in the ruling party, army, and central government.
} 
Van den Berghe 1981) or preexisting social categories (Roeder 2001), this study assumes that the salience of particular ethnic cleavages is shaped by the strategic choice of leaders to ensure their political survival. By integrating institutional understanding of politics with the instrumentalist notion of ethnicity (Bates 1983), it is able to show that ethnic exclusion can actually be in the leader's interest.

Specifically, this study yields three major findings. In non-democratic systems with small winning coalitions: (1) leaders who promote ethnic exclusion are more likely to survive longer in office than those who do not promote such policy; (2) leaders are more likely to be removed from office in a violent manner (e.g. coup d'état, revolt, assassination) when they fail to employ ethnic exclusion; and (3) political benefits from ethnic exclusion are large enough to offset the risk of being involved in internal armed conflicts. Overall, these findings suggest that ethnic exclusion can be "good politics" for autocratic leaders (in a way that serves their political survival) even if it increases the risk of civil war. Furthermore, they have important implications for scholars and policymakers who seek to prevent ethnic violence. Indeed, a number of articles and policy reports contend that ethnic exclusion is a principal source of ethnic violence and, therefore, must be eliminated to restore peace and stability in conflict-affected states (Lewis 1965; Lijphart 1977; Elbadawi and Sambanis 2000; Gurr 2000; World Bank 2011; Hegre and Nygard 2012). I do agree that ethnic exclusion is bad policy for the excluded population. However, the proposed theory specifies the conditions under which the promotion of cooperative and inclusive ethnic policy can be less effective or even dangerous, at least for the leader.

The following section reviews the literature on ethnic exclusion and conflict and describes how this study contributes to existing debates on these topics. The subsequent section develops an argument that explains how institutions for selecting leaders create different incentives for leaders to employ ethnic exclusion. Here I extend the formal logic of the selectorate theory (Bueno de Mesquita et al. 2003) to account for the role of ethnic identity in the formation of ruling coalitions before testing the extension empirically with data on the tenures of more than 1,500 leaders between 1946 and 2012. The final section offers a summary of the key findings of the study and discusses policy implications.

\section{LITERATURE REVIEW}

Ethnic exclusion and inequality play a central role in contemporary civil war literature. In his research on ethnic minorities, Gurr $(1993,2000)$ argued that a 
group's collective disadvantages vis-à-vis other social groups are indirect sources of rebellion that act through grievances and group mobilization. Adopting the concept of "horizontal inequalities" between culturally defined groups, Stewart (2008) argued that both economically underprivileged and politically excluded groups are more easily mobilized for participation in a rebellion. Similarly, based on geo-referenced survey data on welfare and socioeconomic inequalities in 22 sub-Saharan African countries, Østby et al. (2009) found that regional inequalities, in terms of education and household assets, are positively associated with civil war onset. Relying on the Ethnic Power Relations (EPR) data set, Cederman et al. (2010) provided evidence that ethnic groups excluded from state power are more likely to challenge the state than are included groups; this effect is more pronounced when excluded groups have recently experienced a "downgrade" in their power status. Cederman et al. (2011) also demonstrated that both wealthy and poor ethnic groups are more likely to experience civil war than are those groups with average wealth in highly unequal societies.

More recently, Choi and Kim (2016) suggest that excluded groups are most likely to rebel against the government in autocratic systems with small ruling coalitions. Because such regimes provide little opportunity to replace the incumbent through nonviolent means, excluded ethnic groups may come to perceive armed rebellion as a necessary strategy to overthrow the present regime. In addition, Asal, Findley, Piazza, and Walsh (2016) find that excluded groups who are residing in oil-rich territories may demand a greater share of revenues from oil production. When their demand is not met, they organize a rebellion in their name.

While the scholarship mentioned thus far has identified conditions under which we can expect ethnic conflict, other scholars have attempted to explain why some ethnic groups become subject to political exclusion in the first place. Several studies have focused on the relationship between ethnic exclusion and competition for political goods. According to Bates (1983), ethnicity serves as the basis of political coalitions in Africa by enabling group members to secure goods and services from the modern sector and by excluding others from these benefits. In his words, ethnicity provides "a form of minimum winning coalition, large enough to secure benefits in the competition for spoils but also small enough to maximize the per capita value of these benefits" (Bates 1983, 165). Wimmer (2013) took a historical perspective and argued that ethno-political exclusion is an outcome of modern state formation. When elites in weakly centralized states are unable to deliver public goods to the whole population, he notes, they choose to form an exclusive exchange network with their own ethnic communities. 
Fearon (1999) also suggested that ethnic exclusion mostly occurs in patronagebased politics where winners of the election want to maximize the share of the spoils by limiting the size of ruling coalitions. According to Caselli and Coleman (2006), ethnicity serves this purpose well because, as a "visual marker," it is difficult to modify and is convenient to exclude losers. Also based on a study of ethnic politics in India, Chandra (2004) showed that voters tend to support an ethnic political party which has a favorable history of allocating jobs and services to co-ethnics and has a reasonable chance of winning. ${ }^{3}$

Taken together, these studies indicate that 1) ethnic exclusion increases the likelihood of civil conflict and 2) ethnic groups are more likely to be subject to political exclusion in patronage-based political systems. However, what is missing from their analysis is an appreciation of political benefits or costs that an exclusive ethnic policy brings to individual leaders. If policies of ethnic exclusion are a means to benefit members of a particular ethnic group(s), why do leaders care about the welfare of their co-ethnics instead of the broader public? Moreover, why do some leaders foster ethnic exclusion even if such policy increases the risk of internal armed conflict, which might put their tenure in danger? This article attempts to fill this gap in understanding the strategic incentives of leaders who choose to employ ethnic exclusion rather than inclusion.

Roessler (2011) attempted to explain the strategic logic behind ethnic exclusion. Based on original data on the ethnicity of coup leaders and insurgents in sub-Saharan Africa, he argued that, in Africa, the policy of ethnic exclusion reduces the risk of coup d'état at the cost of increasing the risk of rebellion. In line with Roessler, this study shows that ethnic exclusion can decrease the coup risk; yet it departs from previous scholarship by broadening the empirical scope to the entire group of leaders and by examining how political institutions and ethnic politics jointly affect leader survival. This approach not only subsumes existing explanations of ethnic exclusion based on the competition for political goods, but also goes beyond them to derive novel implications for the relationship between ethnic exclusion and leader survival in different institutional contexts.

\footnotetext{
${ }^{3}$ See also Posner (2004), who investigates how the size of ethnic groups influences the political salience of group identity. He shows that Chewa-Tumbuka cleavage is highly salient in Malawi but not in a neighboring Zambia because Chewas and Tumbukas are large enough to serve as viable coalitions in Malawi but are too small to constitute such coalitions in Zambia.
} 


\section{ETHNIC EXCLUSION, COALITION SIZE, AND LEADER SURVIVAL}

This section provides the theoretical foundations of the arguments made in this article. After specifying basic concepts and assumptions, I develop a model that explains how a leader's ethnic policy-that is, ethnic exclusion or inclusion-and the size of the minimum winning coalition interact to influence leader survival. This section concludes with the derivation of three testable hypotheses.

\section{CONCEPTS AND ASSUMPTIONS}

An important assumption of the theory is that leaders make the strategic choice of coalition identity-a key identity that establishes the criteria for determining who constitutes the ruling coalition-that they think will best ensure their political survival. Leaders may choose their own ethnic identity as the basis of their coalition. Before Idi Amin came to power in 1971, for example, members of the Lango and Acholi ethnic groups dominated the government and military in Uganda. However, Amin was a Kakwa; once in power, he filled his coalition with Kakwa officers to the exclusion of Langis and Acholis (Horowitz 2000[1985], 487-492). A coalition identity may also take the form of sub-ethnic cleavages, such as ethno-regional, ethno-linguistic, or tribal identities. Saddam Hussein created his coalition based on a "Sunni Arab north-west," which corresponds to his ethno-regional identity (Tripp 2007, 219). The ruling coalition of Juvénal Habyarimana was largely dominated by northern Hutus-especially those from the northwestern province of Rwanda. During his rule, northern Hutus monopolized control of key government positions to the exclusion of Hutus from the south (Straus 2006, 23). A similar example can be found in Burundi under President Jean-Baptiste Bagaza (1976-1987) where "Bururi Tutsis" dominated the incumbent's coalition to the exclusion of Tutsis from other provinces and many other Hutus (Ngaruko and Nkurunziza 2005, 42-43). In Zambia, leaders used ethno-linguistic identities in national elections and tribal identities in local elections (Posner 2004).

As indicated by the above examples, the concept of ethnic identity employed here is not equal to nominal ethnic categories-such as Shia Muslim, Sunni Muslim, Hutu, Tutsi-that are commonly used to calculate the ethno-linguistic fractionalization (ELF) index (Roeder 2001). Instead, this study follows the definition of ethnicity proposed by Chandra (2006), which defines ethnic identity as a subtype of identity categories whose membership is determined based on descent-based attributes (e.g. skin color, eye color, language, religion, and parents' place of birth). The salience of a particular subset of those attributes is then a function of the leader's strategy shaped by political institutions (Chandra 
and Wilkinson 2008; Posner 2004; Scarritt and Mozaffar 1999). In this sense, my argument is more in line with the "instrumentalist" view that ethnicity is socially constructed by elites for instrumental purposes. ${ }^{4}$

Of course, not every leader chooses ethnicity as his or her coalition identity. For instance, political coalitions in advanced industrialized democracies tend to form along non-ethnic lines such as political ideology (Wagner and Kritzinger 2012), party identity (Richardson 1991), or socio-economic status (Simmons 1967). Regardless of whether identity is based on ethnic or non-ethnic factors, every coalition identity is assumed a deliberate choice made by the leader.

Another key concept is the size of the ruling coalition. No leader can rule alone. To stay in power, leaders must maintain support from coalition members. One of the institutional properties that defines a political system is the size of the minimum winning coalition (W), which is the minimum number of supporters in the selectorate that a leader needs to stay in power (Bueno de Mesquita et al., 2003, 90; Riker, 1962). As a general rule, liberal democracies require larger minimum winning coalitions than do authoritarian regimes. $\mathrm{W}$ is typically about half of the selectorate in competitive two-party presidential systems with simple majority voting, while it can be much smaller than one-quarter in military dictatorships or rigged electoral systems where a small elite group's support can ensure political survival (Bueno de Mesquita et al. 2003, 54-55).

The size of the minimum winning coalition is conceptually distinguished from the actual size of the ruling coalition. The number of supporters in the ruling coalition is not necessarily equal to W; rather, it can be larger or smaller than $\mathrm{W}$. The coalition is "minimum-sized" if the actual size of the ruling coalition corresponds to W, "undersized" if the actual coalition is small when W is large, or "oversized" if it is large when W is small (Choi and Kim 2016, 5-6). Domestic politics have seen many instances where leaders fail to form a minimum-sized coalition. ${ }^{5}$ Oversized coalitions may arise when leaders in small-W systems embrace ethnic rivals for a variety of reasons, including risk of rebellion, pressure from external aid donors (e.g. Burundi and Rwanda in the early 1990s), or ideological beliefs. For example, Abd al-Karim Qasim ruled Iraq between 1958 and 1963. During his term in office, Iraq was a small-W system where the military holds a near monopoly on political power (Andrews and Ra'anan 1969, 73; Choi 2014, 467). However, Qasim had an integrative vision for Iraq and thus tried to include civilians with diverse ethnic and ideological backgrounds

\footnotetext{
${ }^{4}$ For the definition of instrumentalist approach to ethnicity, see Esman (1994, 10-11).

${ }^{5}$ Gallagher et al. (2006) found that only 46 percent of 518 governments formed between 1945 and 2003 in Western and Eastern Europe can be classified as minimum-sized coalition.
} 
in his ruling coalition (Tripp, 2007, 146-147; Choi 2014, 467). The next section offers reasons as to why failure to pursue an exclusive ethnic policy produces an oversized coalition in small-W systems, which in turn contributes to violent leadership turnover. Having discussed necessary concepts and assumptions, I turn next to a specification of the proposed theoretical framework.

\section{THEORETICAL ARGUMENT}

The basic ideas underlying the argument are borrowed from the selectorate theory, which associates the distribution of political goods-public and private goods - with the size of the minimum winning coalition (Bueno de Mesquita et al. 2003). Bueno de Mesquita et al. (2003) assumes that the primary goal of all leaders is political survival, and to survive in office, they must maintain their winning coalition by providing a mix of private and public goods to coalition members. Public goods, such as national defense and highway systems, are those that cannot be withheld from anyone without withholding them for everyone. Hence, public goods benefit all members of the society-both inside and outside the coalition-if they are provided. On the other hand, private goods, such as cash, jobs in state-owned companies, and luxuries for the ruling class, are rival in consumption and excludable. Thus, leaders can restrict access to private goods to members of their winning coalition (Bueno de Mesquita et al. 2003, 29-31). As a result, while everyone in the selectorate benefits from public goods, only those included in the leader's coalition benefit from private goods.

As $\mathrm{W}$ increases, it becomes more difficult and expensive to provide every coalition member with private goods because of a limited budget. Hence, leaders with large winning coalitions rely more on public goods than on private goods to retain the support of their coalition (Bueno de Mesquita et al. 2003, 91-92; Heger and Salehyan 2007; Lake and Baum 2001). In contrast, when $\mathrm{W}$ is small, it is easier for leaders to reward their supporters through private benefits. Moreover, the value of private goods increases in smaller coalitions as individual members can receive a larger share of benefits, which makes private goods a more attractive means to buy support. Therefore, leaders with small winning coalitions shift the mix toward private goods to reward key supporters (Bueno de Mesquita et al. 2003, 91-92; Heger and Salehyan 2007). Take the example of Saddam Hussein's small coalition. His coalition was made up of his clan members from north-western Iraq-only 500,000 out of a population of 26 million (Tripp 2007, 259). These coalition members occupied key government positions and enjoyed privileged access to valuable state resources and opportunities (Choi 2014, 456). Food and other resources were more widely distributed in their home region of Takrit during economic hardship, and even 
the black market and smuggled goods were used as private benefits to loyal supporters (Balaghi 2006, 98; Bueno de Mesquita et al. 2003, 202).

Here, I extend the selectorate theory with an eye toward ethnic ties to clarify why leaders sometimes prefer to pursue the policy of ethnic exclusion. What determines how many people want to join the incumbent's coalition? One major influence is the amount of political goods individuals receive for coalition membership (Bates 1983; Caselli and Coleman 2006; Fearon 1999). The more benefits available for each coalition member, the more willing individuals are to join the leader's coalition. This means that people are less willing to join coalitions in large-W systems that provide only few private goods to coalition members. Here lies the tragedy of large-coalition leaders: to survive, they need large numbers of supporters although entry to their coalition is not profitable enough. One way to address this dilemma is to form an inclusive coalition based on non-ethnic identity, such as ideological beliefs, which can be chosen by anyone who wants to join their coalition (Chandra 2006, 414-416; Fearon 1999, 16-17). It is also evident why large-coalition leaders do not want to exclude any ethnic groups: doing so increases the risk of losing office by allowing the challenger to incorporate excluded groups in his or her coalition without needing to attract them away from the incumbent's. Therefore, it would be political suicide to form an exclusive coalition in large-W systems.

In contrast, when $\mathrm{W}$ is small, more people are willing to join the ruling coalition due to the large amount of private goods provided to each coalition member. The tragedy of small-coalition leaders is that they must exclude large numbers of supporters from the coalition, even though these people want to be coalition members. Because survival in office depends on the provision of private goods to a small group of key supporters, small-coalition leaders have a strong incentive to limit the size of their coalition by preventing entry of outsiders. Leaders can achieve this purpose by requiring anyone who joins the coalition to have a particular set of ethnic identities (e.g. Northern Hutu, Northwestern Sunni). This strategy is most effective when the leader chooses an ethnic identity that certain group of people cannot possess (Fearon 1999, 16-17). For instance, it would be extremely difficult-if not impossible-to change one's skin color if a coalition is formed among individuals with particular ethno-racial characteristics. Such an identity reduces transaction costs of enforcing coalition membership because it helps identify who is real and who may be disguising his or her identity, making the coalition less subject to infiltration by ethnic others (Caselli and Coleman 2006).

Further, an exclusive coalition based on ethnicity increases the loyalty of coalition members to the incumbent leader. The loyalty norm is generated by the 
risk of exclusion from a successful challenger's future ruling coalition (Bueno de Mesquita et al. 2003, 65-68). When coalitions are organized along ethnic lines, access to private benefits is also structured along ethnic lines. Suppose two rival ethnic groups, A and B, are in a fictitious small-W system where the incumbent's coalition represents group A and the challenger's coalition represents group B. In these circumstances, members of group A would fear that, if the incumbent were deposed and the challenger entered office, the probability would be high that members of group B would exclude them from access to private goods. Such a high risk of exclusion from the challenger's coalition drives group A's loyalty to the incumbent leader. The risk of exclusion might not only be related to their access to private goods, but also to their physical survival in an ethnically divided society. For example, when Michel Micombero, a Tutsi, came to power in Burundi, he acted ruthlessly to eliminate Hutus who held high military and government positions under the previous regime. Similarly, Habyarimana executed key figures - mostly southern Hutus-from the previous regime after he seized power in Rwanda. ${ }^{6}$

This theory also explains why leaders in small-W systems do not want to pursue an inclusive ethnic policy: doing so increases the risk of losing office by producing an oversized coalition. When the ruling coalition is organized along non-ethnic lines in small-W systems, the size of the coalition will rapidly expand as large numbers of individuals will try to enter the coalition in order to participate in the distribution of private goods (Fearon 1999, 5). This increase in members not only reduces rewards provided to each coalition member but also weakens members' loyalty to the incumbent leader. Given that political competition in small-W systems is based on the ability to provide private goods, such an inclusive policy makes defection to the challenger more likely. Taken together, these are theoretical reasons why it is rational to form an ethnically exclusive coalition in small-W systems.

As such, I provide a theoretical argument that links ethnic exclusion to the size of the ruling coalition. This does not mean that the only way to build a small ruling coalition is through ethnic blocs. Leaders may form an exclusive coalition

${ }^{6}$ An ethnic coalition is also favored in small-W systems because the leader finds it more effective to distribute benefits on the basis of a bloc identity. Rather than distributing private goods to every individual in the ruling coalition, it is more cost-effective to buy support among a few ethnic elites who can deliver a bloc of votes through patron-client relationships. Ethnicity can provide an attractive basis for a bloc of votes. Members of the ethnic group are likely to support the same candidate as their group leader because they can easily know who will be the beneficiaries of private goods once a candidate endorsed by their leader comes to power. For more information, see Bueno de Mesquita et al. (2003, 63-64); Chandra (2004). 
using other markers, such as class, military or party membership. ${ }^{7}$ However, this study assumes that in countries where ethnicity is politically salient, ethnic identity is a powerful tool for leaders to organize political coalitions and control the allocation of state resources (Bates 1983; Caselli and Coleman 2006; Chandra 2004; Fearon 1999; Heger and Salehyan 2007). Therefore, my argument is more relevant to countries that contain politically relevant ethnic groups (Cederman et al. 2010, 99).

Figure 1. Supply and Demand for Coalition Membership.

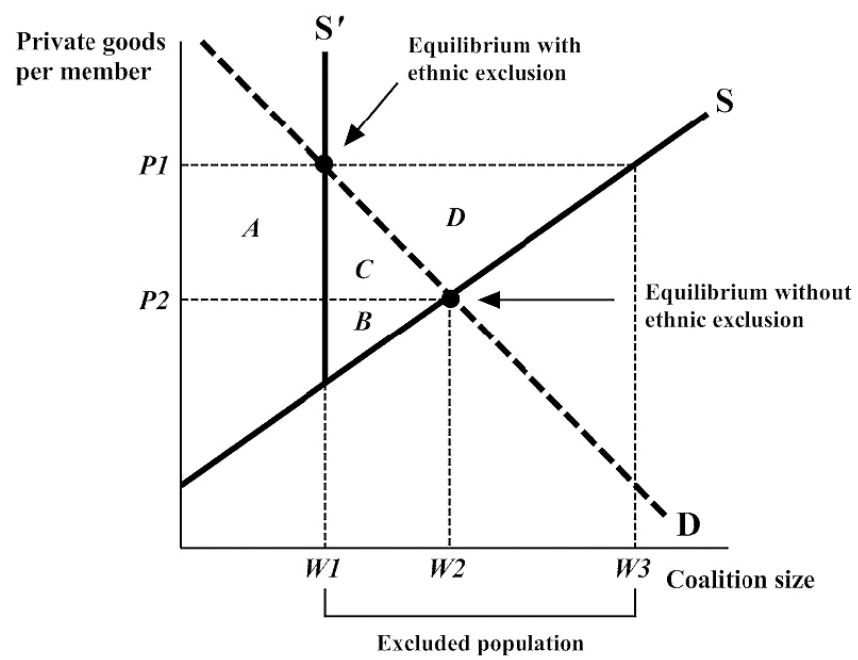

Note: The $y$-axis represents the amount of private goods per coalition member.

The $x$-axis represents the size of the incumbent's coalition.

Figure 1 graphically depicts the causal mechanism of the exclusion model. The demand curve, labeled D in Figure 1, shows how the size of the coalition demanded for leader's survival changes as the amount of private goods received by each coalition member changes. This demand curve is downward sloping,

${ }^{7}$ Even in such cases, ethnic backgrounds (or descent-based attributes) can be used to discriminate against certain groups of people. Consider the example of South Korea under military rule between 1961 and 1987. Although South Korea was considered by many as a homogenous society, father's place of birth (Bonjok) had been printed on the national identity card during this period. It had been widely believed that people from the southwestern (Honam) provinces were discriminated by ruling elites from the southeastern (Yongnam) provinces. 
as suggested by the selectorate theory; the larger the coalition, the less leaders are able to provide coalition members with private goods. On the other hand, the supply curve, labeled S, shows how the number of coalition memberships supplied by citizens depends on the amount of private goods provided to each coalition member. This supply curve is upward sloping-that is, holding other things equal, more citizens will want to join the coalition as the amount of private benefits increases.

Let's suppose a leader in a small-W system $(\mathrm{W}=\mathrm{W} 1)$ initially provides coalition members with a large amount of private goods-say, P1 in Figure 1. This leader has the incentive to form a minimum-sized coalition of size W1, while citizens want a larger coalition of size $\mathrm{W}_{3}-$ a situation in which the coalition supplied exceeds the coalition demanded. What would happen if the leader's coalition is based on a non-ethnic identity that anyone can claim? The imbalance between the supply and demand for coalition membership would create downward pressure for the amount of private goods (per coalition member) as citizens outside the coalition tried to enter the coalition and the leader did not block their entry. Eventually, the ruling coalition would expand until its size reaches W2, resulting in an oversized coalition. This outcome makes both the leader and existing coalition members worse off as the leader is less likely to survive in office with an oversized coalition and existing coalition members receive a smaller amount of private goods, P2.

Alternatively, the same leader can maintain a minimum-sized coalition by requiring that any individual who is a coalition member have a particular ethnic identity that no one can readily alter. If a group of size W1 possesses this identity, the supply curve becomes the vertical line S' at W1. As a result, the system

Figure 2. A Typology of Coalition Size and Expected Leadership Survival.

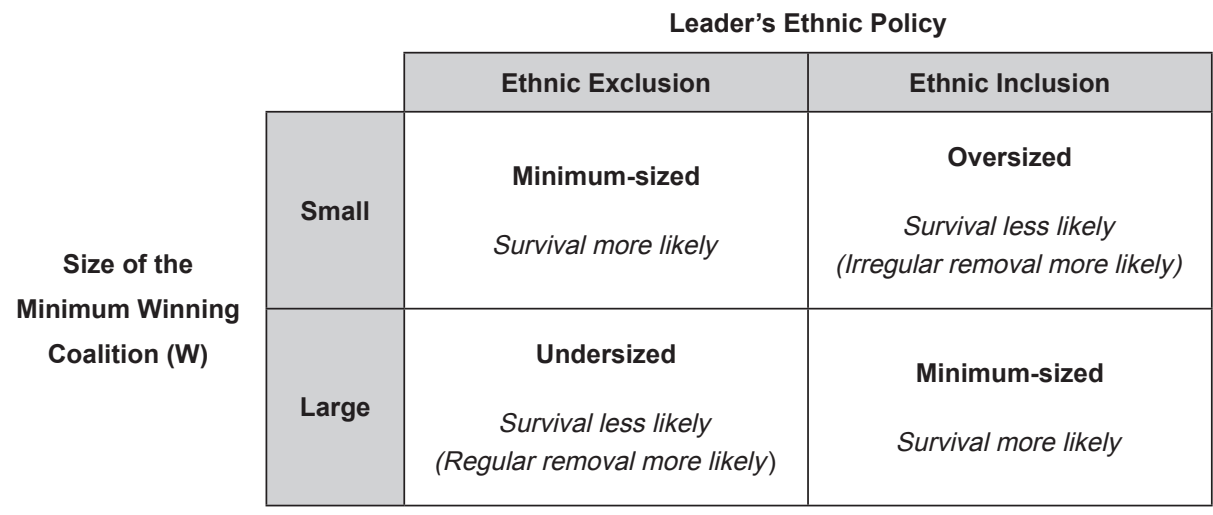


clears at a higher amount of private goods P1 and a smaller coalition size W1. Compared to the equilibrium without ethnic exclusion, coalition members gain rectangle $\mathrm{A}$ by receiving higher amounts of private goods, while those who are excluded by the policy lose triangle $\mathrm{B}$. In addition, the sum of triangles $\mathrm{B}+\mathrm{C}+\mathrm{D}$ represents grievances of excluded groups (of size W3-W1) because they cannot gain this area due to ethnic exclusion, given the higher amount of private goods P1. Although ethnic exclusion reduces the welfare of the excluded, it makes both the leader and coalition members better off because the leader is more likely to remain in office with a minimum-sized coalition and coalition members enjoy larger amounts of private goods. The proposed theoretical framework is summarized in Figure 2. ${ }^{8}$

\section{Hypotheses}

Having specified the causal mechanisms, I now move on to look at the observable implications of the exclusion theory. The first hypothesis concerns the relationship between ethnic exclusion and leadership tenure. Although one might expect that leaders who promote ethnic integration deserve a long tenure in office, my theory suggests that the opposite is true in small-W systems. When $\mathrm{W}$ is small, leaders who pursue an exclusionary ethnic policy would have longer terms in office because such policy prevents an oversized coalition. Therefore, I hypothesize that

Hypothesis 1: Leaders who promote ethnic exclusion are more likely to stay longer in office than are those who do not promote ethnic exclusion in small-W systems.

In addition, I expect that leaders are more likely to be replaced in a violent manner if they do not employ ethnic exclusion in small-W systems. Ethnic inclusion, and the resulting expansion of coalition in small-W systems, decreases the welfare of existing members in the leader's coalition (by rectangle A in Figure 1). Thus, in order to return their welfare to the previous higher level, dissatisfied coalition members might attempt to displace the incumbent in an irregular manner. They can carry out a coup d'état, revolt, or assassination

8 Examples of oversized regimes include Iraq 1958-1963, 2003-2009, Burundi 1989-1993, Rwanda 1989-1994, and Afghanistan 2002-2010, while examples of undersized regimes include Mozambique 1995-2006, Bolivia 1982-2005, Sri Lanka 1956-1963, and Zimbabwe 1970-1978. For more details on this typology, see Choi and Kim (2016). 
as a means to achieve this end (Bueno de Mesquita et al. 2003, 397). ${ }^{9}$ This process can be especially violent when inclusive ethnic policy is preceded by a long period of exclusive rule. The longer the ruling elite profits from the smallcoalition system, the less likely they are to relinquish their privilege without a fight. This makes them more determined to use violence as a means to assert power when their power and privilege are deeply threatened. Through a coup or other means of irregular turnover, they eventually want to install a new leader who can advance their interests in a smaller coalition. Based on this argument, I derive the following hypothesis:

\section{Hypothesis 2: Leaders who do not promote ethnic exclusion are more likely to be removed from office in an irregular manner than are those who promote ethnic exclusion in small-W systems.}

Both Hypothesis 1 and Hypothesis 2 suggest that ethnic exclusion is good politics for leaders in small-W systems because it enhances their prospects for remaining in office. However, this argument raises a critical question: Is ethnic exclusion good politics even if it increases the probability of facing armed conflict? The proposed theory suggests that it is rational to promote ethnic exclusion despite the increased risk of civil war. Among leaders who lost power in an irregular manner between 1946 and 2012, 217 (77\%) were removed by insiders of the ruling coalition (e.g. coup plotters), while only 64 (23\%) were removed by outsiders of the coalition (e.g. rebels)..$^{10}$ As threats posed by ruling elites are far more dangerous than those from external challengers, a rational leader will choose an exclusive strategy that helps avoid internal threats (Roessler 2011).

Further, ethnic exclusion can be good politics even under the worst case scenario where the leader is involved in civil war. In small-W systems, the key positions in the military are often filled by members of the leader's ethnic group.

${ }^{9}$ Other scholars have made similar arguments although they do not directly address the problem of leadership survival. Wimmer (2013) and Wimmer et al. (2009) suggest that increasing the number of power sharing elites increases the likelihood of coalition infighting by making commitment problems more severe and increasing the fear of losing access to government spoils. Roessler (2011) also shows that ethnic exclusion reduces the risk of coup attempts but at the cost of increasing the likelihood of civil war in Africa.

${ }^{10}$ These figures are based on the variable EXITCODE in the Archigos data (Goemans et al. 2008). I assume that leaders were irregularly removed by "insiders" of the coalition if they were removed by domestic military or government actors or by a power struggle within military, and by "outsiders" if they lost power a result of popular protest, rebellion, or assassination by unsupported individual. 
For example, Bashar al-Assad filled almost all key positions in the Syrian army and security services with members of the Alawite minority. Under Saddam Hussein, members of the Sunni north-west held a near-monopoly on key posts in the Republican Guard and regular armed forces. All commanders of Sierra Leone's army were Limba under the Stevens regime. Because these individuals in the military are so closely tied with the incumbent in terms of ethnicity, their ethnic identity signals potential disloyalty to the challenger's future coalition, resulting in a high risk of purging if the current leader is overthrown and the rival group comes to power (McLauchlin 2010). Thus, the loyalty of the military is especially high when a small-coalition leader employs an "ethnic preference policy" in the armed forces (McLauchlin 2010). As victory is essential for access to private goods, these military members also fight hard in the face of rebellion, thus making the incumbent more likely to win the conflict. I summarize this reasoning in my third hypothesis:

Hypothesis 3: During civil war, leaders who promote ethnic exclusion are less likely to lose power than are those who do not promote ethnic exclusion in small-W systems.

\section{RESEARCH DESIGN}

This study uses Cox's semi-parametric proportional hazards models, with leader-years as the unit of analysis. ${ }^{11}$ The dependent variable is the length of time leaders survive in office before leaving office in a particular manner. Data on leadership tenure comes from the Archigos data set, which provides information on the time and manner-regular or irregular-of leaders' entry into and departure from office in 188 countries from 1875 to 2015 (Goemans et al., 2008). For the theory to work, ethnic exclusion should be a feasible policy option. Hence, I restrict the sample only to countries where politically relevant ethnic groups are present..$^{12}$ Because the baseline hazard may vary across countries due to unobserved heterogeneity, all models are stratified by country.

To measure the size of the minimum winning coaition, I use the electoral

11 I tested the proportional hazards assumption based on the analysis of Schoenfeld residuals (Box-Steffensmeier and Jones 2004, 131-133).

12 I follow the criteria used by Cederman et al. (2010) in classifying an ethnic group as politically relevant. An ethnic group is considered political relevant "if at least one political organization claims to represent it in national politics or if its members are subjected to state-led political discrimination" (Cederman et al. 2010, 99). 
democracy index, or "Polyarchy", developed by the Varieties of Democracy (V-Dem) project (Coppedge et al. 2015). This index is constructed using five indicators of electoral democracy: (1) the level of suffrage; (2) clean and fair election; (3) elected executive; and (4) the freedom of association and (5) expression between elections. ${ }^{13}$ The V-Dem's Polyarchy index is a reasonable measure of W since it embodies essential elements of "selection institutions" that regulate how leaders are chosen and replaced (Bueno de Mesquita et al. 2003, 51). Moreover, this variable is not defined by a country's ethnic profile or status of minority rights; this allows me to test how a leader's ethnic policy and $\mathrm{W}$ interact to influence leader survival. For the ease of comparing its effect with other variables, the Polyarchy index is normalized to the scale of o to 1 . Bueno de Mesquita et al. (2003, 134-135) also estimated the size of W although they acknowledged that their measurement of $\mathrm{W}$ is "crude and primitive." As a robustness check, I repeat the analysis using Bueno de Mesquita et al. (2003)'s index as an alternative proxy for $\mathrm{W}^{14}$

The second major independent variable is ethnic Exclusion. Based on the EPR data set, I estimate the degree of ethnic exclusion as the proportion of powerless or discriminated ethnic group(s) in the total ethnopolitically relevant population in a given country and year (Cederman et al. 2010). ${ }^{15}$ Among 146 group-level episodes of conflict onset between 1946 and 2005, 87 (60\%) were fought by powereless or discriminated ethnic groups (Cederman et al. 2010, 102). Thus, if a large proportion of excluded ethnic group(s) was found to enhance political survival, this would be strong evidence that ethnic exclusion is good politics despite the increased risk of civil war.

Figure 3 illustrates the distribution of the Exclusion variable by V-Dem's W between 1946 and 2012. For each range of W, the box contains the median and interquartile range of Exclusion. The figure highlights substantial variation in the proportion of excluded ethnic group(s) when $\mathrm{W} \leq 0.4$, suggesting that inclusive ethnic policies are common, rather than exceptional, in small-W systems. This effectively allows me to test how oversized coalitions affect the survival of leaders. Also noteworthy is that few leaders exclude more than half of the population when $\mathrm{W}>0.8$. This is not surprising since a large number of

${ }^{13}$ For details on the construction of this variable, see V-Dem Codebook v5 (Coppedge et al. 2015, 43).

${ }^{14}$ The results of robustness tests are reported in Appendix 1.

${ }^{15}$ For a definition of powerless or discriminated ethnic group, see EPR-ETH v.2.o Codebook, Accessed at http://www.icr.ethz.ch/data/growup/epr-eth. I did not include the category of "separatist autonomy" in my measure of ethnic exclusion because separatist groups have chosen to exclude themselves from the governing coalition rather than being excluded by the leader's ethnic policy. 
Figure 3. Distribution of Exclusion by W

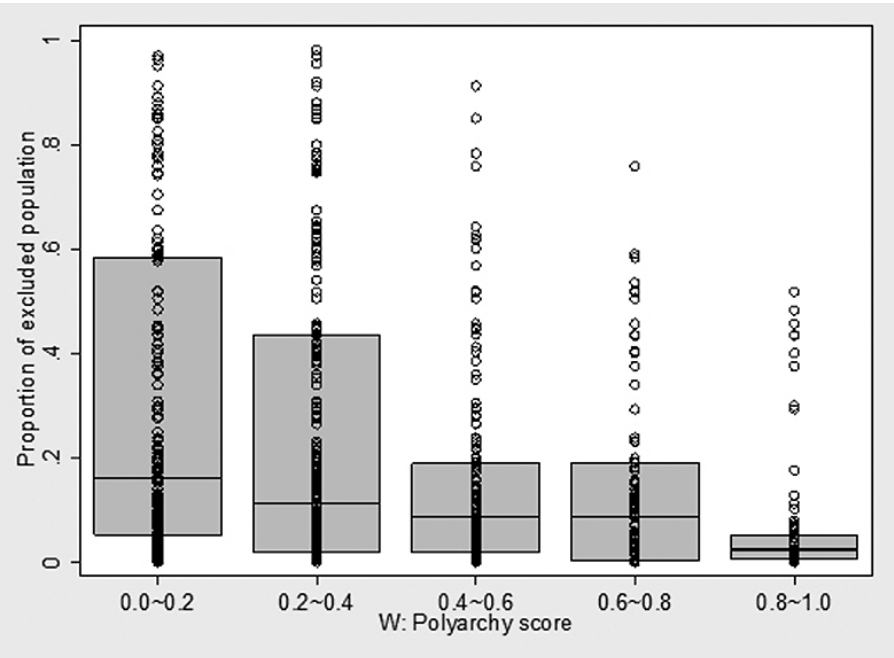

supporters is necessary to maintain power in large-W systems.

To investigate the effects of civil war on leadership tenure, I include a dichotomous variable Civil War that equals 1 if a leader is engaged in a civil war that reaches a threshold of 25 battle-related deaths within a given year based on the UCDP/PRIO Armed Conflict Dataset (Gleditsch et al. 2002). Control variables at the leader-level include the leader's Age, the Manner of Entry into office, and the number of Previous Times in office, all taken from Goemans et al. (2008). I expect a positive coefficient on Age because older leaders are more likely to experience difficulty promising future benefits to coalition members than are younger leaders (Bueno De Mesquita and Smith 2010, 943). The manner of Entry is coded as $\mathrm{O}$ if a leader came into power through a regular process and 1 if through an irregular process (e.g. as a result of a coup d'état). Here, I am interested in examining how the manner with which a leader comes to power affects the hazard of losing office in a specific manner.

Other controls at the country-level include GDP per capita, Population, and Economic Growth. I include the natural log of gross domestic product per capita (GDP per capita) and logged country Population as indicators of socioeconomic development and demographic conditions. Economic Growth is measured by dividing the current year's GDP by the previous year's GDP; this variable has been found to be a highly significant predictor of leadership tenure, with increases in economic growth resulting in decreases in the risk of deposition (Bueno De Mesquita and Smith 2010; Debs and Goemans 2010; Goemans 
2008). These variables are taken from World Bank (2017). Table 1 provides summary statistics for all independent variables.

Table 1. Summary Statistics for Independent Variables

\begin{tabular}{lrcrr}
\hline \multicolumn{1}{c}{ Variable } & Mean & Std. Dev. & \multicolumn{1}{c}{ Min } & Max \\
\hline Exclusion & 0.190 & 0.249 & 0.000 & 0.980 \\
W (Polyarchy) & 0.459 & 0.283 & 0.000 & 1.000 \\
Civil War & 0.195 & 0.396 & 0.000 & 1.000 \\
Age & 57.011 & 11.174 & 17.000 & 93.000 \\
Entry & 0.219 & 0.414 & 0.000 & 1.000 \\
Previous Times & 0.148 & 0.451 & 0.000 & 4.000 \\
Log(GDP per capita) & 7.295 & 1.526 & 3.444 & 11.914 \\
Log(Population) & 16.247 & 1.423 & 12.592 & 21.029 \\
Economic Growth & 4.169 & 8.732 & -64.047 & 251.576 \\
\hline
\end{tabular}

Figure 4. Survival of Leaders in Small-W Systems ( $W<0.5)$, by Exclusion.

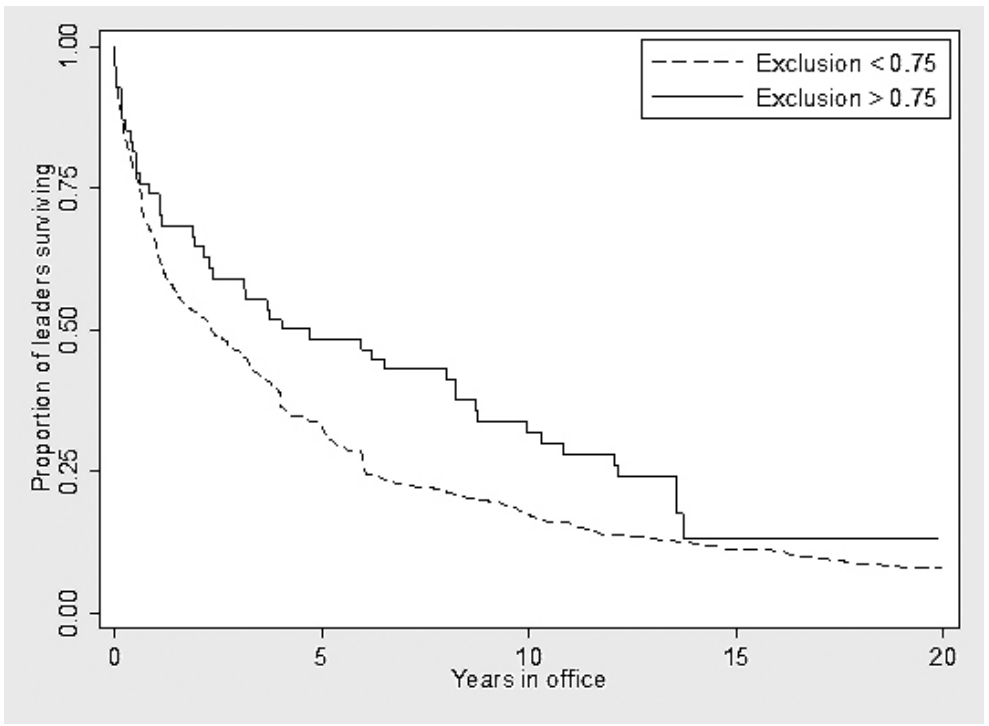

Note: The survival function is estimated by the Kaplan-Meier method. 


\section{NONPARAMETRIC ANALYSIS}

Before performing regression analyses to test the proposed hypotheses, it appears relevant to let the data "speak" for themselves by making no assumptions about the functional form of the survivor function. For the purpose of presentation, a leader is classified as "exclusive" if Exclusion $>0.75$ and "inclusive" if Exclusion $\leq 0.75$. Figure 4 plots the Kaplan-Meier estimates of the survivor function for both types of leaders in small-W systems $(\mathrm{W}<0.5)$. As predicted by the theory, exclusive leaders find it easier to survive than inclusive leaders when $\mathrm{W}$ is small. The curve representing the survival function of exclusive leaders is at each time above the one representing the survival function of inclusive leaders. By the end of ten years, about 32 percent of exclusive leaders remain in office, whereas only 18 percent of inclusive leaders remain. The median survival times for exclusive and inclusive leaders are 4.4 years and 2.3 years, respectively. The log-rank test rejects the null hypothesis of the equality of the two survival functions (chi-square $=4.61, \mathrm{p}=0.032$ ). The following section provides statistical tests using regression analysis.

\section{RESULTS}

Models 1-3 in Table 2 examine the effects of ethnic exclusion on leadership tenure by including the Exclusion and $W$ variables and their multiplicative interaction term. In Model 1, the negative coefficient estimate on the Exclusion variable indicates that the practice of ethnic exclusion significantly decreases the risk of losing office for small-W leaders, which lends support to Hypothesis 1. In small-W systems $(W=O)$, the hazard of losing office for leaders who substantially exclude ethnic out-groups from the ruling coalition (Exclusion=0.9) is 50\% lower than that of leaders who do not employ such a policy (Exclusion=O). In large-W systems $(W=1)$, the effect of ethnic exclusion is the sum of the coefficients on Exclusion and its interaction with W. This aggregate effect is positive and statistically significant at the 0.01 level, suggesting that ethnic exclusion increases the risk of losing office for large-W leaders. In addition, the presence of Civil War influences leader survival. In times of civil war, the hazard of deposition increases by $33 \%$ for all leaders.

The control variables provide additional insight into the logic of leader survival. The positive coefficient for Age tell us that the hazard of losing office is about $2 \%$ higher for each additional year of a leader's age. Concerning the number of Previous Times in office, the hazard rate for those who have repeatedly served 
in their offices tends to be lower than that for those with no such experience. Additionally, the growth rate of GDP also significantly influences survival. For every 1\% increase in Economic Growth, the hazard of losing office is about 2\% lower. The negative coefficient for Population indicates that leaders in countries with large populations find it easier to survive. The coefficients on GDP per capita and Manner of Entry are not distinguishable from zero.

Table 2. Ethnic Exclusion, Coalition Size, and Leader Survival

\begin{tabular}{|c|c|c|c|}
\hline \multirow[b]{2}{*}{ Variables } & \multicolumn{3}{|c|}{ Cox Proportional Hazard Regression } \\
\hline & $\begin{array}{l}\text { (1) } \\
\text { Pooled }\end{array}$ & $\begin{array}{c}(2) \\
\text { Regular }\end{array}$ & $\begin{array}{c}\text { (3) } \\
\text { Irregular }\end{array}$ \\
\hline Exclusion & $\begin{array}{c}-0.824^{* * *} \\
(0.316)\end{array}$ & $\begin{array}{c}-1.268^{* * *} \\
(0.405)\end{array}$ & $\begin{array}{c}-1.048^{* *} \\
(0.532)\end{array}$ \\
\hline W (Polyarchy) & $\begin{array}{c}0.100 \\
(0.244)\end{array}$ & $\begin{array}{l}0.660^{* *} \\
(0.271)\end{array}$ & $\begin{array}{c}-3.972^{* * *} \\
(0.629)\end{array}$ \\
\hline $\mathbf{W} \times$ Exclusion & $\begin{array}{c}2.795^{\star \star *} \\
(0.791)\end{array}$ & $\begin{array}{c}3.917^{* * *} \\
(0.927)\end{array}$ & $\begin{array}{l}3.372^{*} \\
(1.755)\end{array}$ \\
\hline Civil War & $\begin{array}{c}0.282^{* \star *} \\
(0.094)\end{array}$ & $\begin{array}{c}0.072 \\
(0.110)\end{array}$ & $\begin{array}{c}0.786^{* * *} \\
(0.186)\end{array}$ \\
\hline Age & $\begin{array}{c}0.024^{* * *} \\
(0.003)\end{array}$ & $\begin{array}{c}0.025^{\star \star \star} \\
(0.004)\end{array}$ & $\begin{array}{c}0.021^{* * *} \\
(0.007)\end{array}$ \\
\hline Entry & $\begin{array}{c}0.135 \\
(0.092)\end{array}$ & $\begin{array}{l}0.219^{*} \\
(0.121)\end{array}$ & $\begin{array}{l}-0.263 \\
(0.161)\end{array}$ \\
\hline Previous Times & $\begin{array}{c}-0.206^{* * *} \\
(0.052)\end{array}$ & $\begin{array}{c}-0.243^{\star * *} \\
(0.060)\end{array}$ & $\begin{array}{c}0.031 \\
(0.116)\end{array}$ \\
\hline Log(GDP per capita) & $\begin{array}{l}-0.021 \\
(0.036)\end{array}$ & $\begin{array}{l}-0.028 \\
(0.040)\end{array}$ & $\begin{array}{l}-0.065 \\
(0.090)\end{array}$ \\
\hline Log(Population) & $\begin{array}{c}-0.415^{\star * *} \\
(0.101)\end{array}$ & $\begin{array}{c}-0.244^{* *} \\
(0.118)\end{array}$ & $\begin{array}{c}-0.813^{* * *} \\
(0.214)\end{array}$ \\
\hline Economic Growth & $\begin{array}{c}-0.020^{* * *} \\
(0.004)\end{array}$ & $\begin{array}{l}-0.011^{* *} \\
(0.005)\end{array}$ & $\begin{array}{c}-0.047^{* * *} \\
(0.010)\end{array}$ \\
\hline Log-likelihood & -2660.36 & -2177.79 & -421.59 \\
\hline Observations & 7,860 & 7,860 & 7,860 \\
\hline Number of leaders & 1,533 & 1,533 & 1,533 \\
\hline Number of failures & 1,399 & 1,118 & 269 \\
\hline
\end{tabular}

Note: ${ }^{*} \mathrm{p}<.1,{ }^{* *} \mathrm{p}<.05,{ }^{* * *} \mathrm{p}<.01$ (two-tailed tests), Robust standard errors in parenthesis. 
In Model 1, the event of interest was whether or not leaders lose office; however, there are different ways in which leaders exit office. Goemans (2008) identified two distinct ways of exit: a regular and an irregular exit. Leaders can lose office in a regular manner due to electoral defeat, term limits, or ill health; they can also be removed from office in an irregular manner as a result of "the threat or use of force," such as a coup, revolt, or assassination (Goemans 2008, 4-5). For this reason, I perform a competing risks analysis in which I distinguish the two different types of exit. In so doing, I can obtain a more refined estimate of the association of ethnic exclusion and $\mathrm{W}$ with a particular way of losing office.

Models 2 and 3 suggest that, in small-W systems, ethnic exclusion decreases the hazard of deposition in both a regular and an irregular manner. In Model 2, the coefficient estimate on the Exclusion variable is negative and statistically significant at the 0.01 level, suggesting that ethnic exclusion decreases the hazard of "regular" turnover in small-W systems $(W=O)$. For a change in Exclusion from o to 0.9, the estimated hazard of regular turnover among small-coalition leaders drops by $64.7 \%$, holding all other variables constant. In Model 3, ethnic exclusion has a negative and significant effect on the hazard of "irregular" turnover in small-W systems $(W=O)$, thus supporting Hypothesis 2. I find that the risk of violent removal from office among small-coalition leaders who exclude $90 \%$ of the ethnopolitically relevant population (Exclusion=0.9) is only $41.5 \%$ of the risk experienced by those who do not employ any form of exclusion (Exclusion $=O$ ). There is also a positive and significant interaction between Exclusion and $W$, which indicates that the effect of ethnic exclusion on the irregular loss of office turns to positive with increasing $\mathrm{W}$.

Figures 5 plot the predicted hazard ratios generated from Model 1. Dots and vertical bars represent the predicted hazard ratios and their $95 \%$ confidence intervals for hypothetical small-coalition leaders $(W=O)$ with different levels of ethnic exclusion. The reference category, which is shown as a horizontal dashed line, is a large-coalition leader $(W=1)$ with no ethnic exclusion (Exclusion=o). Figure 5 provides compelling evidence that the survival of leaders depends on the level of ethnic exclusion employed in small-W systems. Compared with the reference group, the estimated hazard ratio is 0.77 (95\% CI, 0.49 to 1.20) for small-coalition leaders with low levels of ethnic exclusion (Exclusion=0.2). When they employ the highest level of exclusion, the hazard ratio drops to 0.40 ( $95 \%$ CI, 0.21 to 0.73 ).

Next, I examine the relationship between ethnic exclusion and civil war in small-W systems. Figures 6 plots the predicted hazard ratios for small-coalition leaders $(W=O)$ with different levels of ethnic exclusion in times of civil war (Civil 
Figure 5. Predicted Hazard Ratios in Small-W Systems.

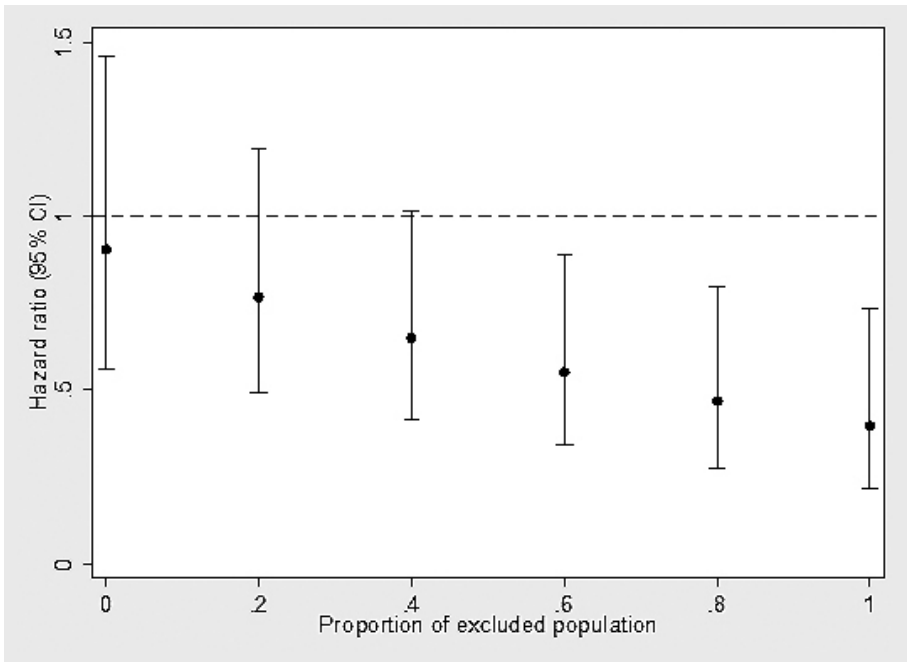

Note: The reference category (dashed line) represents the hazard rate for a large-coalition leader $(W=1)$ who does not employ ethnic exclusion $($ Exclusion $=0)$. All other variables are held at their means. Figure 5 uses estimates from Model 1.

Figure 6. Predicted Hazard Ratios during Civil War in Small-W Systems.

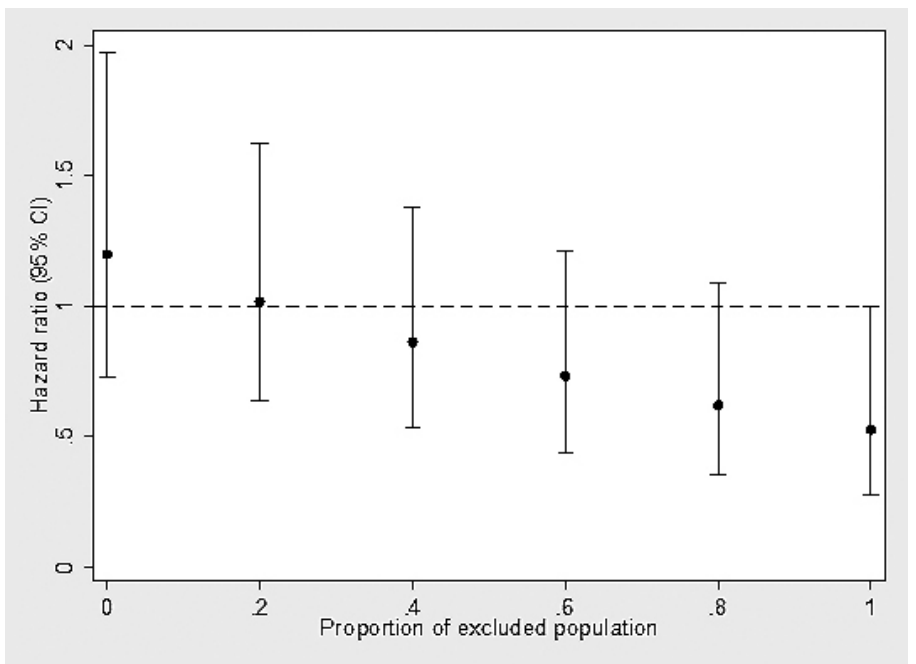

Note: The reference category (dashed line) represents the hazard rate for a large-coalition leader $(W=1)$ who does not employ ethnic exclusion $($ Exclusion= $=0$ in peaceful times (Civil War $=0$ ). All other variables are held at their means. Figure 6 uses estimates from Model 1. 
War=1). The reference category is a large-coalition leader $(W=1)$ without ethnic exclusion (Exclusion $=O$ ) in times of peace (Civil War=o). Figure 6 shows that small-coalition leaders who employ higher levels of ethnic exclusion face lower hazards of losing office during civil war. When compared with the reference group, the hazard ratio is 0.53 (95\% CI, 0.28 to 0.99 ) for highly exclusive leaders (Exclusion=1.0). This result suggests that, when $\mathrm{W}$ is small, exclusive leaders tend to enjoy better survival prospects than do inclusive leaders even if the former is involved in civil war and the latter is not, providing support for Hypothesis 3.

Regarding the control variables, both Economic Growth and larger Population decrease the risk of both types of turnover, although their effects are stronger and more significant for the irregular loss of office. The number of Previous Years in office do not have significant effects on the irregular removal from power; however, they do significantly decrease the hazard of a regular removal. The effect of Civil War is highly significant for the risk of an irregular turnover but have less of relationships to the risk of a regular turnover. These results show that each mode of exit can be influenced by different mechanisms and the two approaches-pooled and competing risks models-can result in different conclusions in terms of the effects of individual variables on leadership survival.

\section{CONCLUSION}

This article started with a simple question: Why do some leaders deliberately employ ethnic exclusion even though it increases the risk of ethnic conflict? The political exclusion of ethnic groups and the resulting "grievances" have been recognized as one of the most important causes of civil war (Cederman et al. 2010; Cederman et al. 2011; Gurr 1993, 2000; Horowitz 2000). However, leaders' incentives for ethnic exclusion received scant attention in the existing literature on ethnic conflicts and in many attempts to implement policies designed to resolve ethnic grievances. The central purpose of this article is to emphasize the crucial role of leaders in explaining ethnic exclusion and violence. Contrary to common belief, my findings suggest that ethnic exclusion is good politics for leaders with small winning coalitions because it enhances their prospects for remaining in office, despite its positive impact on the risk of ethnic conflict. The remainder of this concluding section discusses the policy implications of the research.

Scholars and policymakers have supported the idea of "inclusive coalition" as a way to manage conflict in ethnically divided societies. In Politics in West 
Africa, for instance, Lewis (1965) proposed a coalition government in which all the major parties participate in decision-making. Lewis $(1965,67)$ wrote that, in such a system, "It is necessary to get right away from the idea that somebody is to prevail over somebody else; from politics as a zero-sum game. Words like 'winning' and 'losing' have to be banished from the political vocabulary of a plural society". The World Bank (2011) proposed a policy of "inclusive-enough coalition"16 as one of the basic principles for violence prevention and peaceful resolution of conflicts. Former U.S. President Barack Obama also stated that Syrian civil war was "a magnet for extremists and could only end with a political solution leading to a new inclusive government (Reuters 2015)."

Forming an inclusive coalition might be a good policy for the country. However, the proposed theory suggests that such a policy is not necessarily a rational one, at least for the leader if not the citizenry. The promotion of an inclusive coalition in small-W systems gives rise to oversized coalition, making the leader vulnerable to a violent removal from office (Choi and Kim 2016). In particular, when members of one ethnic group have enjoyed exclusive privileges for a long period of time before this policy is implemented, they are unlikely to relinquish their privileges without a bloody fight. This was the pattern of behavior that led to the Rwandan genocide in the early 1990s. When President Habyarimana signed the Arusha Accord to establish a broad-based transitional government with significant Tutsi representation, Rwanda's ruling elites perceived this as a grave threat to their hold on power and to the privileges they had enjoyed under Habyarimana (Straus 2006, 24-25). They adopted hardline stances and chose to keep their power through irregular means, training a youth militia, spreading anti-Tutsi propaganda, and developing "death lists" of moderate Hutus (Straus 2006, 26-31). When Habyarimana was killed in April 1994, the hardliners, who once dominated key positions in the Habyarimana government, were coordinating the genocide that claimed at least 500,000 lives. The identified recommendations for inclusive coalition have not taken an adequate account of this dangerous trade-off that might arise in the course of policy implementation.

What can be learned from the research presented in this article, and what policies should be considered in the future? This study suggests that there is no easy way to simultaneously promote ethnic inclusion and leaders' survival in small-coalition systems. To be sure, a successful transition from an exclusive

\footnotetext{
${ }^{16}$ Inclusive enough coalition is defined as the governing coalition encompassing broader segments of society, including local governments, civil society movements, opposition parties, and in some cases rebel groups. See World Bank (2011, xvii).
} 
toward an inclusive coalition will reduce the risk of ethnic conflict. However, this transition should be accompanied by institutional reforms to increase the size of the minimum winning coalition. To the extent that the incumbent's coalition is oversized, efforts toward an inclusive coalition generate violent outcomes in small-W systems. Hence, only after leaders have undertaken significant institutional reforms toward a large $\mathrm{W}$ can they safely form an ethnically inclusive coalition to escape the vicious cycle of exclusion and violence.

Second, intervention by the international community through organizations such as the United Nations and African Union can facilitate a peaceful transition to a larger and more inclusive coalition by taking defensive measures to protect the incumbent during a transition period. The expansion of coalition in small-W systems decreases the welfare of existing elites. My empirical findings indicate that, faced with the erosion of welfare, they could choose to remove their current leader by force. International actors can reduce this risk by providing an effective protection against any attempts at unconstitutional changes of government. The approval of tougher anti-coup measures by the African Union is therefore a positive development (Witt 2012). Finally, efforts must be made to reassure hardliners in the incumbent's coalition that the transition toward an inclusive governance is not aimed at excluding them, but rather at promoting a stable system that provides all citizens with peace and prosperity.

To conclude, policymakers must be acutely aware that the formation of an inclusive coalition could become another source of violence and instability in small-W systems, especially when such a measure is implemented after years of authoritarian rule based on ethnic exclusion. Those who lack a clear understanding of this grim reality are likely to find that their efforts to build an inclusive governance will end in violence.

\section{REFERENCES}

Allen, Christopher. 1968. "Sierra Leone Politics since Independence." African Affairs 67(269), 305-329.

Andrews, William George, and Uri Ra'anan. 1969. The Politics of the Coup D'état: Five Case Studies. New York: Van Nostrand Reinhold Co.

Banks, Arthur. 2007. Cross-National Time-Series Data Archive User's Manual. Distributed by Databanks International, Jerusalem, Israel.

Bates, Robert H. 1983. "Modernization, Ethnic Competition, and the Rationality of Politics in Contemporary Africa." In D. S. Rothchild and V. A. Olorunsola ed., State Versus Ethnic Claims: African Policy 
Dilemmas. Boulder, Colorado: Westview Press, 152-171.

Box-Steffensmeier, Janet M., and Bradford S. Jones. 2004. Event History Modeling: A Guide for Social Scientists. New York: Cambridge University Press.

Bueno De Mesquita, Bruce, and Alastair Smith. 2010. "Leader Survival, Revolutions, and the Nature of Government Finance." American Journal of Political Science 54(4), 936-950.

Bueno de Mesquita, Bruce, Alastair Smith, Randolph M. Siverson, and James D. Morrow. 2003. The Logic of Political Survival. Cambridge, MA: MIT Press.

Caselli, Francesco, and Wilbur John Coleman. 2006. "On the Theory of Ethnic Conflict.” CEP Discussion Paper No. 732. London: Centre for Economic Performance, London School of Economics and Political Science,.

Cederman, Lars-Erik, Nils B. Weidmann, and Kristian Skrede Gleditsch. 2011. "Horizontal Inequalities and Ethnonationalist Civil War: A Global Comparison." American Political Science Review 105(3), 478-495.

Cederman, Lars-Erik, Andreas Wimmer, and Brian Min. 2010. "Why Do Ethnic Groups Rebel? New Data and Analysis." World Politics 62(1), 87-119.

Chandra, Kanchan. 2004. Why Ethnic Parties Succeed: Patronage and Ethnic Headcounts in India. Cambridge, UK: Cambridge University Press. . 2006. "What is Ethnic Identity and Does It Matter?" Annual Review of Political Science 9(1), 397-424.

Chandra, Kanchan, and Steven Wilkinson. 2008. "Measuring the Effect of 'Ethnicity'." Comparative Political Studies 41(4-5), 515-563.

Choi, Hyun Jin. 2014. "How Ethnic Exclusion Influences Rebellion and Leader Survival: A Simulation Approach." Social Science Computer Review 32(4), 453-473.

Choi, Hyun Jin, and Dongsuk Kim. 2016. "Coup, Riot, War: How Political Institutions and Ethnic Politics Shape Alternative Forms of Political Violence." Terrorism and Political Violence, Forthcoming.

Coppedge, Michael, John Gerring, Staffan I. Lindberg, Jan Teorell, David Altman, Michael Bernhard, M. Steven Fish, Adam Glynn, Allen Hicken, Carl Henrik Knutsen, Kelly McMann, Daniel Pemstein, Svend-Erik Skaaning, Jeffrey Staton, Eitan Tzelgov, Yi-ting Wang, and Brigitte Zimmerman. 2015. "Varieties of Democracy: Dataset v4." Varieties of Democracy (V-Dem) Project.

Cox, Thomas Storke. 1976. Civil-military relations in Sierra Leone. Cambridge, MA: Harvard University Press. 
Debs, Alexandre, and H.E. Goemans. 2010. "Regime Type, the Fate of Leaders, and War." American Political Science Review 104(3), 430-445.

Elbadawi, E, and N Sambanis. 2000. "Why Are There So Many Civil Wars in Africa? Understanding and Preventing Violent Conflict.” Journal of African Economies 9(3), 244-269.

Esman, Milton Jacob. 1994. Ethnic Politics. Ithaca, New York: Cornell University Press.

Fearon, James D. 1999. "Why Ethnic Politics and "Pork" Tends To Go Together." MacArthur Foundation-sponsored Conference on Ethnic Politics and Democratic Stability. Chicago, IL: University of Chicago.

Gallagher, Michael, Peter Mair, and Michael Laver. 1992. Representative Government in Western Europe. New York: McGraw-Hill.

Gleditsch, Nils Petter, Peter Wallensteen, Mikael Eriksson, Margareta Sollenberg, and Havard Strand. 2002. "Armed Conflict 1946-2001: A New Dataset.” Journal of Peace Research 39(5), 615-637.

Goemans, H. E. 2008. "Which Way Out? The Manner and Consequences of Losing Office." Journal of Conflict Resolution 52(6), 771-794.

Goemans, H. E., Kristian Skrede Gleditsch, and Giacomo Chiozza. 2008. ARCHIGOS: A Data Set on Leaders 1875-2004. Accessed at http:// www.rochester.edu/college/faculty/hgoemans/data.htm (January 10, 2012).

Gurr, Ted Robert. 1993. "Why Minorities Rebel: A Global Analysis of Communal Mobilization and Conflict since 1945." International Political Science Review 14(2), 161-201.

. 2000. Peoples Versus States: Minorities at Risk in the New Century. Washington, D.C.: United States Institute of Peace Press.

Heger, Lindsay, and Idean Salehyan. 2007. "Ruthless Rulers: Coalition Size and the Severity of Civil Conflict.” International Studies Quarterly 51(2), 385-403.

Hegre, Havard, and Havard M. Nygard. 2012. Governance and Conflict Relapse. Paper Presented at the International Studies Association Annual Convention, San Diego, CA.

Horowitz, Donald L. 2000. Ethnic Groups in Conflict, 2nd edition. Berkeley: University of California Press.

Isaacs, Harold Robert. 1989. Idols of the Tribe: Group Identity and Political Change. Cambridge, MA: Harvard University Press.

Lake, David A., and Matthew A. Baum. 2001. "The Invisible Hand of Democracy: Political Control and the Provision of Public Services.” Comparative Political Studies 34(6), 587-621. 
Lewis, William Arthur. 1965. Politics in West Africa. London: Allen \& Unwin. Lijphart, Arend. 1977. Democracy in Plural Societies: A Comparative Exploration. New Haven: Yale University Press.

Marshall, Monty G., and Benjamin R. Cole. 2011. "Global Report 2011: Conflict, Governance, and State Fragility." Accessed at http://www. systemicpeace.org/GlobalReport2011.pdf (May 5, 2012).

Marshall, Monty G., and Keith Jaggers. 2011. "Polity IV Dataset and Users' Manual: Political Regime Characteristics and Transitions, 18002010." Accessed at http://www.systemicpeace.org/polity/polity4.htm (January 8, 2012).

McLauchlin, Theodore. 2010. "Loyalty Strategies and Military Defection in Rebellion." Comparative Politics 42(3), 333-350.

Morrow, James D., Bruce Bueno de Mesquita, Randolph M. Siverson, and Alastair Smith. 2008. "Retesting Selectorate Theory: Separating the Effects of W from Other Elements of Democracy." American Political Science Review 102(3), 393-400.

Ngaruko, Floribert, and Janvier D. Nkurunziza. 2005. "Civil War and Its Duration in Burundi." In P. Collier and N. Sambanis ed., Understanding Civil War: Evidence and Analysis. Washington DC: The World Bank, 35-61.

Østby, Gudrun, Ragnhild Nordås, and Jan Ketil Rød. 2009. "Regional Inequalities and Civil Conflict in Sub-Saharan Africa." International Studies Quarterly 53(2), 301-324.

Posner, Daniel N. 2004. "The Political Salience of Cultural Difference: Why Chewas and Tumbukas Are Allies in Zambia and Adversaries in Malawi." American Political Science Review 98(4), 529-545.

Riker, William H. 1962. The Theory of Political Coalitions. New Haven: Yale University Press.

Roeder, Philip G. 2001. "Ethnolinguistic Fractionalization (ELF) Indices, 1961/1985." Accessed at http://weber.ucsd.edu/ proeder/elf.htm (October 20, 2012).

Roessler, Philip. 2011. "The Enemy Within: Personal Rule, Coups, and Civil War in Africa." World Politics 63(2), 300-346.

Scarritt, James R., and Shaheen Mozaffar. 1999. "The Specification of Ethnic Cleavages and Ethnopolitical Groups for the Analysis of Democratic Competition in Contemporary Africa." Nationalism and Ethnic Politics 5(1), 82-117.

Singer, J. David, and Melvin Small. 2006. Correlates of War Project: International and Civil War Data, 1816-1992. MI: Inter-University 
Consortium for Political and Social Research.

Smith, Anthony. 1986. The Ethnic Origin of Nations. Oxford: Blackwell.

Stewart, Frances. 2008. "Horizontal Inequalities and Conflict: An Introduction and Some Hypotheses.” In F. Stewart ed., Horizontal Inequalities and Conflict: Understanding Group Violence in Multiethnic Societies. Basingstoke: Palgrave Macmillan, 3-24.

Storey, David. 2015. "Obama Says 'No Meeting of Minds' with Russia on Syria." Reuters (October 17).

Straus, Scott. 2006. The Order of Genocide: Race, Power, and War in Rwanda. Ithaca: Cornell University Press.

Tripp, Charles. 2007. A History of Iraq, 3rd editon. Cambridge: Cambridge University Press.

Van den Berghe, Pierre L. 1981. The Ethnic Phenomenon. New York: Elsevier. Wimmer, Andreas 2013. Waves of War: Nationalism, State Formation, and Ethnic Exclusion in the Modern World. Cambridge: Cambridge University Press.

Wimmer, Andreas, Lars-Erik Cederman, and Brian Min. 2009. "Ethnic Politics and Armed Conflict: A Configurational Analysis of a New Global Data Set." American Sociological Review 74(2), 316-337.

Witt, Antonia. 2012. "Jointly Working for Democracy? The African Union and Unconstitutional Changes of Government." Paper Presented at the the DVPW Kongress, Tübingen, Germany (September 24-28).

World Bank. 2011. World Development Report 2011: Conflict, Security, and Development. Washington, DC: World Bank.

World Bank. 2017. "World Development Indicators." Accessed at http://data. worldbank.org/data-catalog/world-development-indicators (August 1, 2017). 
Appendix 1 reports robustness checks of the main results in Table 2 using Bueno de Mesquita et al. (2003)'s measure of W. This variable is constructed using four indicators of W: (1) military versus civilian regime (Arthur Banks 2007); (2) the competitiveness of executive recruitment; (3) the openness of executive recruitment; and (4) the competitiveness of political participation (Marshall and Jaggers 2011).* The coefficient for Exclusion is negative and statistically significant at the 0.01 level in Model 3 only. This suggests that ethnic exclusion decreases the risk of losing office for small-W leaders, but this effect is driven by the reduction of the risk of deposition in an irregular manner.

Appendix 1. Robustness Tests Using Bueno de Mesquita et al. (2003)'s W

\begin{tabular}{|c|c|c|c|}
\hline \multirow[b]{2}{*}{ Variables } & \multicolumn{3}{|c|}{ Cox Proportional Hazard Regression } \\
\hline & $\begin{array}{c}\text { (1) } \\
\text { Pooled }\end{array}$ & $\begin{array}{c}(2) \\
\text { Regular }\end{array}$ & $\begin{array}{c}\text { (3) } \\
\text { Irregular }\end{array}$ \\
\hline Exclusion & $\begin{array}{l}-0.286 \\
(0.300)\end{array}$ & $\begin{array}{l}-0.050 \\
(0.429)\end{array}$ & $\begin{array}{c}-1.236 \\
(0.467)^{\star * *}\end{array}$ \\
\hline W (Bueno de Mesquita et al.) & $\begin{array}{c}-0.279 \\
(0.219)\end{array}$ & $\begin{array}{c}1.267 \\
(0.272)^{\star \star *}\end{array}$ & $\begin{array}{c}-4.574 \\
(0.493)^{\star * *}\end{array}$ \\
\hline $\mathbf{W} \times$ Exclusion & $\begin{array}{c}0.360 \\
(0.528)\end{array}$ & $\begin{array}{c}0.397 \\
(0.651)\end{array}$ & $\begin{array}{c}2.942 \\
(1.184)^{\star *}\end{array}$ \\
\hline Civil War & $\begin{array}{c}0.286 \\
(0.093)^{\star \star \star}\end{array}$ & $\begin{array}{c}0.051 \\
(0.109)\end{array}$ & $\begin{array}{c}0.626 \\
(0.197)^{\star * *}\end{array}$ \\
\hline Age & $\begin{array}{c}0.024 \\
(0.003)^{\star * *}\end{array}$ & $\begin{array}{c}0.022 \\
(0.004)^{\star * *}\end{array}$ & $\begin{array}{c}0.029 \\
(0.008)^{\star * *}\end{array}$ \\
\hline Entry & $\begin{array}{c}0.009 \\
(0.098)\end{array}$ & $\begin{array}{c}0.398 \\
(0.129)^{\star \star *}\end{array}$ & $\begin{array}{c}-0.615 \\
(0.178)^{\star * *}\end{array}$ \\
\hline Previous Times & $\begin{array}{c}-0.178 \\
(0.051)^{\star * *}\end{array}$ & $\begin{array}{c}-0.225 \\
(0.059)^{* * *}\end{array}$ & $\begin{array}{c}0.029 \\
(0.124)\end{array}$ \\
\hline Log(GDP per capita) & $\begin{array}{c}-0.014 \\
(0.034)\end{array}$ & $\begin{array}{l}-0.030 \\
(0.037)\end{array}$ & $\begin{array}{l}-0.042 \\
(0.092)\end{array}$ \\
\hline Log(Population) & $\begin{array}{c}-0.268 \\
(0.088)^{\star \star *}\end{array}$ & $\begin{array}{l}-0.048 \\
(0.103)\end{array}$ & $\begin{array}{c}-1.032 \\
(0.200)^{\star * *}\end{array}$ \\
\hline Economic Growth & $\begin{array}{c}-0.019 \\
(0.004)^{\star \star *}\end{array}$ & $\begin{array}{c}-0.012 \\
(0.005)^{\star *}\end{array}$ & $\begin{array}{c}-0.045 \\
(0.009)^{\star * *}\end{array}$ \\
\hline Log-likelihood & -2731.61 & -2229.07 & -384.47 \\
\hline Observations & 8,144 & 8,144 & 8,144 \\
\hline Number of leaders & 1,561 & 1,561 & 1,561 \\
\hline Number of failures & 1,428 & 1,143 & 285 \\
\hline
\end{tabular}

Note: ${ }^{*} \mathrm{p}<.1,{ }^{* *} \mathrm{p}<.05,{ }^{* * *} \mathrm{p}<.01$ (two-tailed tests), Robust standard errors in parenthesis.

*For details on the construction of this variable, see Bueno de Mesquita et al. (2003, 133-135). 
Next, I include the natural log of annual Military Expenditures (in current US dollars) as an additional control variable (Singer and Small 2006). One possible challenge to the causal impact of ethnic exclusion in small-W systems is regime/leader strength; a strong leader may not only sustain his or her rule, but also keep a large excluded majority in check. If this is the case, both leadership tenure and ethnic exclusion could be manifestations of the same, external variable. Tests including Military Expenditures allow me to separate the effects of ethnic exclusion from regime strength, thereby promoting an assessment of the independent effects of ethnic exclusion on leadership survival. Appendix 2 shows that my results are robust to control for regime strength.

Appendix 2. Robustness Tests with the Control of Annual Military Expenditures

\begin{tabular}{|c|c|c|c|}
\hline \multirow[b]{2}{*}{ Variables } & \multicolumn{3}{|c|}{ Cox Proportional Hazard Regression } \\
\hline & $\begin{array}{c}\text { (1) } \\
\text { Pooled }\end{array}$ & $\begin{array}{c}\text { (2) } \\
\text { Regular }\end{array}$ & $\begin{array}{c}\text { (3) } \\
\text { Irregular }\end{array}$ \\
\hline Exclusion & $\begin{array}{c}-0.878^{* * *} \\
(0.332)\end{array}$ & $\begin{array}{c}-1.414^{* * *} \\
(0.437)\end{array}$ & $\begin{array}{c}-1.091^{* *} \\
(0.545)\end{array}$ \\
\hline W (Polyarchy) & $\begin{array}{l}-0.024 \\
(0.257)\end{array}$ & $\begin{array}{l}0.538^{*} \\
(0.284)\end{array}$ & $\begin{array}{c}-4.114^{\star * \star} \\
(0.694)\end{array}$ \\
\hline $\mathbf{W} \times$ Exclusion & $\begin{array}{c}2.842^{\star \star *} \\
(0.869)\end{array}$ & $\begin{array}{c}4.211^{* \star *} \\
(1.031)\end{array}$ & $\begin{array}{l}4.093^{* *} \\
(1.888)\end{array}$ \\
\hline Civil War & $\begin{array}{c}0.310^{* * *} \\
(0.100)\end{array}$ & $\begin{array}{c}0.079 \\
(0.118)\end{array}$ & $\begin{array}{c}0.819^{* * *} \\
(0.192)\end{array}$ \\
\hline Age & $\begin{array}{c}0.022^{* * *} \\
(0.003)\end{array}$ & $\begin{array}{c}0.024^{\star * *} \\
(0.004)\end{array}$ & $\begin{array}{l}0.017^{* *} \\
(0.007)\end{array}$ \\
\hline Entry & $\begin{array}{c}0.059 \\
(0.098)\end{array}$ & $\begin{array}{c}0.164 \\
(0.131)\end{array}$ & $\begin{array}{l}-0.278^{*} \\
(0.163)\end{array}$ \\
\hline Previous Times & $\begin{array}{c}-0.203^{* * *} \\
(0.053)\end{array}$ & $\begin{array}{c}-0.239^{* * *} \\
(0.062)\end{array}$ & $\begin{array}{c}0.003 \\
(0.120)\end{array}$ \\
\hline Log(GDP per capita) & $\begin{array}{l}-0.036 \\
(0.042)\end{array}$ & $\begin{array}{l}-0.020 \\
(0.047)\end{array}$ & $\begin{array}{l}-0.067 \\
(0.096)\end{array}$ \\
\hline Log(Population) & $\begin{array}{c}-0.522^{* * *} \\
(0.133)\end{array}$ & $\begin{array}{l}-0.213 \\
(0.155)\end{array}$ & $\begin{array}{c}-1.109^{* * *} \\
(0.291)\end{array}$ \\
\hline Economic Growth & $\begin{array}{c}-0.019^{* * *} \\
(0.005)\end{array}$ & $\begin{array}{l}-0.010^{*} \\
(0.005)\end{array}$ & $\begin{array}{c}-0.050^{* * *} \\
(0.010)\end{array}$ \\
\hline Log(Military Expenditures) & $\begin{array}{c}0.030 \\
(0.032)\end{array}$ & $\begin{array}{l}-0.016 \\
(0.035)\end{array}$ & $\begin{array}{c}0.051 \\
(0.070)\end{array}$ \\
\hline Log-likelihood & -2345.76 & -1896.98 & -394.14 \\
\hline Observations & 7,138 & 7,138 & 7,138 \\
\hline Number of leaders & 1,404 & 1,404 & 1,404 \\
\hline Number of failures & 1,271 & 1,002 & 269 \\
\hline
\end{tabular}

Note: ${ }^{*} \mathrm{p}<.1,{ }^{* *} \mathrm{p}<.05,{ }^{* * *} \mathrm{p}<.01$ (two-tailed tests), Robust standard errors in parenthesis. 
